\title{
PENGARUH FAKTOR KLINIS DAN KETERATURAN MINUM OBAT DENGAN TERJADINYA TB MDR DI WILAYAH KERJA PUSKESMAS KECAMATAN PASAR REBO JAKARTA TIMUR
}

"Petrus Geroda Beda Ama ${ }^{1)}$, Suhermi ${ }^{2}$, Futi Fradilla ${ }^{3)}$

${ }^{1,3)}$ S1 Kesehatan Masyarakat, Fakultas Kesehatan, Universitas Mohammad Husni Thamrin

${ }^{2)}$ DIII-MPRS, Fakultas Kesehatan, Universitas Mohammad Husni Thamrin

Correspondence author: petrusgeroda@ gmail.com, Jakarta, Indonesia

DOI: https://doi.org/10.37012/jik.v12i1.115

\begin{abstract}
ABSTRAK
Penyakit Tuberkulosis masih menjadi masalah kesehatan masyarakat yang utama di Indonesia, baik dalam hal prevalensinya maupun masalah-masalah lain yang ditimbulkan. Upaya dalam penanggulangan penyakit Tuberculosis ini pun masih terus dilakukan, namun dalam perjalanannya banyak hambatan dalam upaya tersebut, salah satunya adalah adanya fenomena Tuberkulosis Multidrug Resistant (TB-MDR). Penelitian tentang faktor yang berpengaruh juga sudah banyak dilakukan, namun terkait faktor klinis dan kepatuhan minum obat masih perlu untuk ditelusuri lagi. Tujuan dari penelitian ini adalah untuk mengetahui pengaruh faktor klinis dan kepatuhan minum obat dengan terjadinya TB-MDR, dengan Desain penelitian adalah kasus kontrol. Populasi dan sampel adalah pasien TB biasa dan TB-MDR di di wilayah kerja Puskesmas Kecamatan Pasar Rebo Jakarta Timur. Hasil penelitian menunjukkan bahwa secara bivariat, faktor-faktor yang berpengaruh terhadap kejadian TB-MDR di wilayah kerja Puskesmas Kecamatan Pasar Rebo Jakarta Timur adalah Riwayat Pengobatan TB (OR 4,702 dengan CI: 1,702-15,221), Efek Obat Anti TB (OR: 6,844 dengan CI: 1,772-26,440), Kepatuhan minum obat (OR: 8,947 dengan CI: 2,299-34,816). Sementara variabel yang tidak berpengaruh adalah Status Gizi dan Riwayat penyakit Diabetes melitus. Hasil Analisis Multivariat, variabel yang paling dominan berpengaruh terhadap kejadian TB-MDR adalah Kepatuhan minum obat (OR: 7,192 dengan CI: 1,644-31,452). Perlu ditingkatkan lagi penyuluhan atau KIE kepada pasien, keluarga dan atau PMO tentang pentingnya kepatuhan minum obat dan konsekuensi yang timbul akibat dari ketidakpatuhan minum obat sangat penting untuk mengendalikan peningkatan kejadian TB MDR.
\end{abstract}

Kata kunci : Tubekulosis, MDR, Faktor Klinis, Kepatuhan Minum Obat.

\begin{abstract}
Tuberculosis is still a major public health problem in Indonesia, both in terms of its prevalence and other problems caused. Efforts in tackling Tuberculosis are still ongoing, but in the course of many obstacles in the effort, one of which is the phenomenon of Tuberculosis Multidrug Resistant (MDR-TB). Research on influential factors has also been done, but related to clinical factors and medication adherence still needs to be explored again. The purpose of this study was to determine the effect of clinical factors and medication adherence with the occurrence of $M D R-T B$, with the study design being a case control. The population and sample were ordinary TB and MDR-TB patients in the working area of the Pasar Rebo District Health Center in East Jakarta. The results showed that bivariate, the factors that influenced the incidence of MDR$T B$ in the working area of the Pasar Rebo District Health Center in East Jakarta were TB Treatment History (OR 4,702 with CI: 1,702-15,221), Effects of Anti-TB Drugs (OR: 6,844 with CI: 1,772-26,440), Compliance with taking medication (OR: 8,947 with CI: 2,299-34,816). While the variables that had no effect were Nutrition Status and History of Diabetes Mellitus. Multivariate Analysis Results, the most dominant variable influencing the incidence of MDR-TB is compliance with taking medication (OR: 7,192 with CI: 1,644-31,452). It is also necessary to increase counseling or IEC to patients, families and or PMO about the importance of adherence to taking drugs and the consequences arising from non-compliance with taking drugs are very important to control the increased incidence of MDR TB.
\end{abstract}

Keywords : Tuberculosis, MDR, Clinical Factors, Compliance With Medication. 


\section{PENDAHULUAN}

Tuberkulosis paru adalah penyakit infeksi menular, di sebabkan oleh bakteri Mycobacterium Tuberkulosis. Menurut WHO 2016, Indonesia merupakan negara dengan jumlah kasus baru terbanyak kedua di dunia setelah India. Indonesia juga tercatat sebagai salah satu dari 27 negara dengan beban MDR TB terberat di dunia. Diperkirakan setiap tahunnya terdapat 6.800 kasus baru MDR TB, atau 2,8\% di antara infeksi baru TB, dan $16 \%$ di antara kasus TB yang sudah menjalani pengobatan. (1)

Pelacakan kasus TBC di DKI Jakarta juga terus ditingkatkan seiring dengan optimalisasi program Ketuk Pintu Layani Dengan Hati, dimana jumlah penderita positif kuman TBC mencapai 37.114 penderita, namun diperlukan perlakuan khusus terhadap khusus terhadap penderita masih banyaknya kasus hilang, minimnya kepatuhan pengobatan dan meningkatnya TBC resisten obat.

Berdasarkan data dari Puskesmas Kecamatan Pasar Rebo, angka prevalensi kejadian TB Paru dengan BTA+ terus meningkat pada 5 kelurahan yang berada di wilayah Kecamatan Pasar Rebo. Pada tahun 2016 terdapat 215 jumlah pasien TB aktif dan diobati, pada tahun 2017 terdapat 244 pasien TB aktif, sedangkan pada tahun 2018 dengan laporan Triwulan 1 dari bulan Januari hingga Maret terdapat 60 pasien TB aktif yang diobati.

Kasus TB-MDR di wilayah Jakarta Timur dari bulan Mei 2018 teridentifikasi sebanyak 85 kasus dari 10 laporan puskesmas Kecamatan yang ada di Jakarta Timur. Kasus tertinggi di Kecamatan Ciracas yaitu 18 kasus diikuti Kecamatan Pasar Rebo dengan jumlah 15 kasus selanjutnya adalah Kecamatan Matraman dan Jatinegara yaitu 2 kasus.

Untuk pasien TB-MDR yang diobati di Puskesmas Kecamatan Pasar Rebo juga mengalami peningkatan dari tahun 2016-2018. Pada tahun 2016 terdapat 2 pasien, pada tahun 2017 meningkat menjadi 7 pasien, hingga pada tahun 2018 tercatat ada 15 pasien TB-MDR aktif dan mendapatkan pengobatan. Selain itu, dilihat dari Angka keberhasilan pengobatan, puskesmas Kecamatan Pasar Rebo juga masih tergolong renda yaitu 66\% pada tahun 2016 dengan target 90\%. Hal ini diperparah juga dengan pasien yang resistensi obat. (3)

Beberapa penelitian terkait TB-MDR, salah satunya dijelaskan dalam penelitian Mulyono (2014) tentang faktor faktor mempengaruhi peningkatan keberhasilan TB-MDR adalah 
kegagalan pengobatan pada TB-MDR, kegagalan tersebut berhubungan dengan usia, jenis kelamin, riwayat pengobatan, efek samping, dokter, pasien, obat-obatan, program nasional TB, terapi yang tidak adekuat, resistensi obat-obatan, konseling, regulasi obat, keterlambatan dalam perawatan, HIV-AIDS, durasi terapi, rendah motivasi, jenuh dalam perawatan, dan biaya pengobatan. Meningkatnya motivasi menjadi solusi untuk mengurangi jumlah ketidakpatuhan dan kegagalan pengobatan pada penderita sehingga mengurangi kejadian TB- MDR. (4)

Nawas (2010) dalam penelitiannya tentang Penatalaksanaan TB MDR dan Strategi DOTS-Plus FKUI, menyebutkan faktor klinis yang menyebabkan resisten obat diantaranya: terlambatnya diagnosis dan isolasi, penggunaan obat yang tidak tepat, mengisolasi penderita, kurangnya pengetahuan tentang TB, pelaksanaan DOTS yang kurang baik dan kurang patuh serta pengobatan tidak lengkap.

Hasil penelitian Munir dkk (2010), menunjukkan bahwa keteraturan berobat dan lama pengobatan berpengaruh terhadap keberhasilan pengobatan penderita TB MDR, dimana terdapat pengaruh yang kuat antara keteraturan berobat dan lama pengobatan terhadap keberhasilan pengobatan. (5) Penelitian lain yang dilakukan oleh Kusnanto 2014, menemukan bahwa riwayat pengobatan TB juga menetukan terjadinya TB MDR. (6)

Berdasarkan uraian diatas, diperkuat dengan hasil penelitian terdahulu maka dugaan sementara, faktor klinis dan kepatuhan minum obat juga merupakan pemicu terjadinya kasus TB-MDR, namun perlu ditelusuri lebih lanjut. Adapun Tujuan dari penelitian ini adalah untuk Mengetahui pengaruh antara faktor klinis dan keteraturan minum obat dengan terjadinya TB-MDR di wilayah Puskesmas Kecamatan Pasar Rebo Jakarta Timur"

\section{METODE}

Penelitian ini merupakan studi observasional (pengamatan) dengan jenis disain studi kasus control. Kasus adalah Penderita TB MDR. Sementara Kontrol adalah Pasien dengan TB Biasa. Populasi dalam penelitian ini adalah semua penderita TB baik MDR maupun Non MDR yang ada di wilayah kerja puskesmas kecamatan Pasar Rebo Jakarta Timur yaitu TB MDR sebanyak 14 orang dan TB Non MDR sebanyak 86 Orang. Sampel dalam penelitian ini diambil dengan sistem populasi total Sampling. 
Pengumpulan data mengunakan kuesioner. Pengolahan data dilakukan dengan bantuan aplikasi perangkat lunak computer. Sementara analisa data yang dilakukan adalah Analisa Univariat, Bivariat. Untuk mengetahui apakah hipotesis (H0) yang diajukan sebelumnya ditolak atau diterima, maka dilakukan uji statistik dengan ketentuan, bila $\mathrm{p}$ value $\leq \alpha$ $(0,05)$ maka H0 ditolak, artinya ada perbedaan yang bermakna, bila $\mathrm{p}$ value $>\alpha(0,05)$ maka,

H0 diterima, artinya tidak ada perbedaan yang bermakna (7)

Besarnya resiko kejadian diukur dengan menggunakan Odds Rasio (OR). Ketentuannya adalah , jika nilai $\mathrm{OR}=1$, estimasi bahwa tidak ada pengaruh antara faktor resiko dengan kasus. Jika OR > 1, Estimasi bahwa ada pengaruh positif antara faktor resiko dengan kasus. Dan jika OR < 1, estimasi bahwa ada hubungan negatif antara faktor resiko. (8)

\section{HASIL DAN PEMBAHASAN}

\section{Hasil Analisis Univariat}

Tabel 1. Distribusi Dan Proporsi Hasil Penelitian Menurut Variabel Independen Dan Dependen

\begin{tabular}{|c|c|c|c|}
\hline Variabel & Kategori & Jumlah & Presentase \\
\hline \multirow[t]{2}{*}{ Status TB } & MDR & 14 & $14 \%$ \\
\hline & Non MDR & 86 & $86 \%$ \\
\hline \multicolumn{2}{|l|}{ Total } & 100 & $100 \%$ \\
\hline \multirow[t]{2}{*}{ Riwayat Pengobatan TB } & Ada Riwayat & 27 & $27 \%$ \\
\hline & Tidak Ada Riwayat & 73 & $73 \%$ \\
\hline \multicolumn{2}{|l|}{ Total } & 100 & $100 \%$ \\
\hline \multirow{2}{*}{ Efek OAT } & Mengganggu & 41 & $41 \%$ \\
\hline & Tidak Mengganggu & 59 & $59 \%$ \\
\hline \multicolumn{2}{|l|}{ Total } & 100 & $100 \%$ \\
\hline \multirow[t]{2}{*}{ Status Gizi } & $<$ IMT & 41 & $41 \%$ \\
\hline & $\geq$ IMT & 59 & $59 \%$ \\
\hline \multicolumn{2}{|l|}{ Total } & 100 & $100 \%$ \\
\hline \multirow[t]{2}{*}{ Diabetes Melitus } & Ada DM & 17 & $17 \%$ \\
\hline & Tidak Ada DM & 83 & $83 \%$ \\
\hline \multicolumn{2}{|l|}{ Total } & 100 & $100 \%$ \\
\hline \multirow[t]{2}{*}{ Kepatuhan Minum Obat } & Tidak Patuh & 36 & $36 \%$ \\
\hline & Patuh & 64 & $64 \%$ \\
\hline \multicolumn{2}{|l|}{ Total } & 100 & $100 \%$ \\
\hline
\end{tabular}


Hasil penelitian univariat pada tabel 1 memperlihatkan bahwa distribusi variabel status TB dibagi menjadi 2 yaitu TB MDR sebagai Kasus dan TB Non MDR sebangai Kontrol. Untuk yang MDR sebanyak 14\% dan Non MDR sebanyak 86\%. Pada variabel riwayat pengobatan TB, proporsi responden yang tidak mempunyai riwayat TB sebelumnya sebesar 73\%. Pada variabel Efek Obat Anti TB, 59\% responden menyatakan bahwa OAT tidak mengganggu. Pada variabel status gizi, sebagian besar responden mempunyai status gizi normal sebesar 59\%. Pada variabel penyakit Diabetes Melitus, sebagian besar responden tidak mempunya penyakit DM yaitu 83\%. Pada variabel kepatuhan minum obat, sebagian besar sudah patuh yaitu sebanyak $64 \%$.

\section{Hasil Analisis Bivariat}

Dalam analisis bivariat ini peneliti menggunakan uji Chi-Square oleh karena semua variabel berbentuk kategorik dengan masing masing 2 kelompok kategori. Untuk lebih jelas, hasil penelitian bivariat dipaparkan dalam tabel 2.

Tabel 2. Analisis Bivariat Pengaruh Faktor Klinis Dan Keteraturan Minum Obat Dengan Terjadinya TB-MDR di Wilayah Puskesmas Kecamatan Pasar Rebo Jakarta Timur

\begin{tabular}{|c|c|c|c|c|c|c|c|c|c|}
\hline \multirow[b]{2}{*}{ Variabel } & \multirow[b]{2}{*}{ Kategori } & \multicolumn{6}{|c|}{ Status Pengobatan TB } & \multirow{2}{*}{$\begin{array}{c}\text { P- } \\
\text { Value }\end{array}$} & \multirow{2}{*}{$\begin{array}{c}\text { OR } \\
95 \% \mathrm{Cl}\end{array}$} \\
\hline & & MDR & $\%$ & $\begin{array}{c}\text { Non } \\
\text { MDR }\end{array}$ & $\%$ & Total & $\%$ & & \\
\hline Riwayat & Ada Riwayat & 8 & 57,1 & 19 & 22,1 & 27 & 44,0 & \multirow{3}{*}{0,019} & \\
\hline Pengobatan TB & Tidk ada Riwayat & 6 & 42,9 & 67 & 77,9 & 73 & 56,0 & & 4,702 \\
\hline Total & & 14 & 100,0 & 86 & 100,0 & 100 & 100,0 & & $(1,702-15,221)$ \\
\hline \multirow[t]{2}{*}{ Efek OAT } & Mengganggu & 11 & 78,6 & 30 & 34,9 & 41 & 100,0 & \multirow{3}{*}{0,005} & \multirow{3}{*}{$\begin{array}{c}6,844 \\
(1,772-26,440)\end{array}$} \\
\hline & Tdk Mengganggu & 3 & 21,4 & 56 & 65,1 & 59 & 100,0 & & \\
\hline Total & & 14 & 100,0 & 86 & 100,0 & 100 & 100,0 & & \\
\hline \multirow[b]{2}{*}{ Status Gizi } & $<$ IMT & 5 & 35,7 & 36 & 41,9 & 41 & 41,0 & \multirow{3}{*}{0,888} & \multirow{3}{*}{$\begin{array}{c}0,772 \\
(0,238-2,496)\end{array}$} \\
\hline & $\geq \mathrm{IMT}$ & 9 & 64,3 & 50 & 58,1 & 59 & 59,0 & & \\
\hline Total & & 14 & 100,0 & 86 & 100,0 & 100 & 100,0 & & \\
\hline \multirow{2}{*}{$\begin{array}{l}\text { Diabetes } \\
\text { Melitus }\end{array}$} & Ada DM & 3 & 21,4 & 14 & 16,3 & 17 & 17,0 & \multirow{3}{*}{0,702} & \multirow{3}{*}{$\begin{array}{c}1,403 \\
(0,346-5,683)\end{array}$} \\
\hline & Tidak ada DM & 11 & 78,6 & 72 & 83,7 & 84 & 84,0 & & \\
\hline Total & & 14 & 100,0 & 86 & 100,0 & 100 & 100,0 & & \\
\hline \multirow{2}{*}{$\begin{array}{l}\text { Kepatuhan } \\
\text { Minum Obat }\end{array}$} & Tdk Patuh & 11 & 78,6 & 25 & 29,1 & 36 & 36,0 & \multirow[b]{3}{*}{0,001} & \multirow{3}{*}{$\begin{array}{c}8,947 \\
(2,299-34,816)\end{array}$} \\
\hline & Patuh & 3 & 21,4 & 61 & 70,9 & 64 & 64,0 & & \\
\hline Total & & 14 & 100,0 & 86 & 100,0 & 100 & 100,0 & & \\
\hline
\end{tabular}

Hasil analisis Pengaruh antara Faktor Klinis pasien dan keteraturan minum obat dengan terjadinya TB MDR pada pasien TB di Puskesmas Kecamatan Pasar Rebo Tahun 2019, dapat dilihat pada tabel 2 diatas. Berdasarkan hasil Uji maka proporsi maupun hubungan variabel independen dengan variabel dependen dapat dibahas sebagai berikut: 


\section{Riwayat Pengobatan TB Terhadap Kejadian TB MDR}

Hasil uji statistik untuk variabel riwayat Ppngobatan TB diperoleh nilai p sebesar 0,019. Berdasarkan hasil ini maka dapat disimpulkan, ada pengaruh antara Riwayat Pengobatan TB sebelumnya dengan terjadinya TB MDR. Hasil uji pula diperoleh Nilai OR sebesar 4,702 dengan CI: 1,702-15,221. Artinya responden yang mempunyai riwayat pengobatan TB sebelumya, berpeluang 6 kali lebih besar untuk terjadinya TB MDR dibanding Responden yang tidak mempunyai Riwayat pengobatan TB Sebelumnya.

Hasil penelitian ini sejalan dengan penelitian yang dilakukan Jana M, (2019) bahwa riwayat pengobatan TB mempunyai pengaruh yang signifikan dengan nilai OR OR 5,3 (9). Hasil serupa juga sejalan juga dengan penelitian potong lintang yang dilakukan oleh (Mekonnen et al., 2015) terhadap 124 responden di Distrik West Armchiho dan Metema Ethiopia, riwayat pengobatan TB memiliki hubungan yang signifikan terhadap kejadian TB MDR dengan OR $=7$ dan p value 0,025 (10).

Asumsi yang dapat disampaikan oleh peneliti adalah pada saat melakukan wawancara sebagian besar responden mempunyai riwayat pengobatan TB sebelumnya, beberapa merupakan pasien kambuh dan putus obat. Status TB dengan kategori 2 pun peneliti temui pada saat melakukan wawancara. Status TB dengan kategori 2 sangat beresiko untuk terjadinya TB-MDR. Jika kambuh kembali maka perlu diperhatikan kepatuhan minum obat serta pertambahan maupun pengurangan berat badannya.

\section{Efek Obat Anti TB Terhadap Kejadian TB MDR}

Hasil Uji statistik untuk variabel Efek Obat Anti TB diperoleh Nilai P sebesar 0,005. Artinya pada alpha 5\% diperoeh nilai $\mathrm{p}<$ alpha. Berdasarkan hasil ini maka dapat disimpulkan, ada pengaruh antara Efek Obat Anti TB dengan terjadinya TB MDR. Hasil uji pula diperoleh Nilai OR sebesar 6,844 dengan CI: 1,772-26,440. Artinya responden yang menyatakan efek obat anti TB "mengganggu", berpeluang 7 kali lebih besar untuk terjadinya TB MDR dibanding Responden yang efek obat anti TB tidak menganggu. Hal ini sejalan dengan penelitian Kusnanto, dkk (2014) yang mengatakan adanya pengaruh yang signifikan antara efek samping OAT dengan pengobatan TB-MDR mual dan muntah (gangguan gastrointestinal) merupakan efek samping yang paling sering ditemukan dibandingkan dengan efek samping lainnya yaitu 79,8\% dan 78,9\%. 
Penelitian yang dilakukan oleh Yuni Riswanti (2014) juga memiliki pengaruh yang signifikan antara efek minum obat dengan gagal konversi $(\mathrm{OR}=5,25)(11)$. Hal ini sejalan dengan penelitian Kusnanto, dkk (2014) yang mengatakan adanya pengaruh yang signifikan antara efek samping OAT dengan pengobatan TB-MDR mual dan muntah (gangguan gastrointestinal) merupakan efek samping yang paling sering ditemukan dibandingkan dengan efek samping lainnya yaitu 79,8\% dan 78,9\%. (12)

Penatalaksanaan klinis TB-MDR lebih rumit bila dibandingkan dengan TB yang sensitif karena menggunakan obat anti-TB (OAT) lini I dan lini II. Pada tatalaksana TB yang sensitif hanya menggunakan 4 obat dan membutuhkan waktu 6 bulan, sedangkan pada tatalaksana MDR TB mempergunakan minimal 5 obat dan berlangsung selama 18 sampai 24 bulan. Tatalaksana kasus MDR TB ini sering dihubungkan dengan kejadian efek samping mulai dari yang ringan sampai yang berat sehingga banyak pasien dari pasien TB-MDR yang mulai mengalami efek samping hingga mengganggu jalannya pengobatan (13)

Menurut wawancara yang dilakukan peneliti, responden dengan status TB-MDR lebih banyak merasakan efek yang merugikan dari OAT, dari efek ringan hingga harus dirujuk ke Rumah Sakit. Efek OAT yang biasanya dirasakan pada pasien TB-MDR adalah sakit perut, mual, gangguan pendengaran, gatal dan kesemutan serta nyeri di ulu hati. Hal tersebut dapat menghentikan pengobatan yang seharusnya dijalani pasien TB dan membuat ketidak percayaan pasien terhadap obat TB sehingga pasien melakukan putus obat dan terjadilah TB-MDR.

\section{Status Gizi Terhadap Kejadian TB MDR}

Hasil uji statistik untuk variabel Status Gizi, diperoleh nilai p sebesar 0,888. Artinya pada alpha 5\% diperoeh nilai $\mathrm{p}>$ alpha. Berdasarkan hasil ini maka dapat disimpulkan, tidak ada pengaruh antara status Gizi dengan terjadinya TB MDR. Hal ini sejalan dengan penelitian Tirtana (2011) yang menyatakan tidak ada hubugan yang bermakna antara status gizi dengan terjadinya TB-MDR dengan nilai $\mathrm{p}=1,00$ (14). Sejalan juga dengan penelitian Mulyanto H (2014) yang mengatakan bahwa perilaku mengonsumsi gizi titak berpengaruh terhadap TB MDR dengan nilai OR 0,25. (15)

Ketidakbermaknaan antara Status gizi dengan kejadian TB MDR ini menurut asumsi peneliti, di puskesmas Pasar Rebo sendiri telah memberikan asupan tambahan berupa 
susu "Proten" kepada seluruh pasien TB yang sedang menjalani pengobatan. Susu tersebut merupakan subsidi pemerintah untuk menaikan status gizi pasien TB

\section{Penyakit Diabetes Melitus Terhadap Kejadian TB MDR}

Hasil uji statistik untuk variabel Penyakit Diabetes Melitus, diperoleh nilai p sebesar 0,702. Berdasarkan hasil ini maka dapat disimpulkan, tidak ada pengaruh antara status penyakit Diabetes Melitus dengan terjadinya TB MDR.

Diabetes mellitus merupakan suatu kelompok penyakit metabolik dengan karakteristik hiperglikemia kronis yang terjadi karena kelainan defek sekresi insulin, kerja insulin, atau kedua-duanya (16). Hal ini sejalan dengan penelitian Alfiana Lia (2013) bahwa tidak diperoleh pengaruh yang signifikan terjadinya TB-MDR pada responden yang memiliki diabetes mellitus dan tidak (9).

Penelitian tersebut juga memilki hasil yang sama dengan penelitian yang dilakukan Tirtana (2011) yaitu tidak ada pengaruh yang bermakna dikarenakan persentase pasien TB-MDR dengan riwayat Diabetes Mellitus (17,7\%) jumlahnya lebih rendah, dibandingkan pasien yang tidak memiliki riwayat Diabetes Mellitus (82,2\%) (14).

Tidak adanya pengaruh antara DM dengan TB-MDR menurut asumsi peneliti disebabkan karena jumlah kasus TB-MDR dengan DM tidak terlalu banyak yang berobat

ke Puskesmas, selain itu harus ada bukti rujukan dari RS yang menyatakan pasien tersebut adalah pasien TB dengan DM ataupun DM dengan TB. Dengan demikian berdasarkan hasil penelitian, Pasien TB perlu diberikan kemudahan dalam hal mendapatkan surat rujukan dari RS agar pasien TB dengan DM dapat melakukan pengobatan di Puskesmas, serta meningkatkan program skrining pada pasien DM karena pasien DM beresiko terkena TB.

\section{Kepatuhan Minum Obat Anti TB Terhadap Kejadian TB MDR}

Hasil Uji statistik untuk Kepatuhan Minum Obat diperoleh nilai P sebesar 0,001. Berdasarkan hasil ini maka dapat disimpulkan, ada pengaruh antara Kepatuhan minum obat dengan terjadinya TB MDR. Hasil uji pula diperoleh Nilai OR sebesar 8,947 dengan CI: 2,299-34,816. Artinya responden yang tidak patu minum obat anti TB, berpeluang 9 kali lebih besar untuk terjadinya TB MDR dibandingkan dengan responden yang patuh minum obat anti TB. 
Ketidak patuhan dalam pengobatan juga menjadi faktor penting dalam berkembangnya resistensi obat. Penyebab terbesar terjadinya resisten obat adalah ketidakpatuhan pasien dalam menjalani pengobatan. Pasien tidak datang berobat (drop out) pada fase intensif karena rendahnya motivasi dan kurangnya informasi tentang penyakit yang dideritanya (17). Hal ini sejalan dengan penelitian yang dilakukan oleh Alfiana Lia (2013) bahwa kepatuhan pengobatan memilki pengaruh yang bermakna dengan terjadinya TB-MDR $(\mathrm{OR}=11,310)$ yang mengatakan bahwa pasien yang tidak patuh terhadap pengobatan lebih beresiko 11 kali lebih besar dari yang patuh (9).

Penelitian serupa juga dilakukan oleh Niviasari, dkk (2017) yang mengatakan ada pengaruh yang bermakna antara keteraturan pengobatan dengan status kesembuhan $(\mathrm{OR}=7,7)$. Dari wawancara yang dilakukan oleh peneliti, sebagian besar pasien yang memiliki status TB kategori 2 maupun TB-MDR setidaknya pernah satu kali tidak meminum obat atau memeriksakan dahak ulang sesuai jadwal yang diajukan petugas kesehatan, adapun alasan responden adalah lupa atau tidak keluarnya dahak sehingga pasien sulit untuk melakukan pemeriksaan dahak ulang. (18)

\section{Hasil Analisis Multivariat}

\section{Seleksi Kandidat}

Seleksi kandidat ini dimaksud untuk mengetahui variabel mana yang layak di ikutkan dalam analisis multivariat. Batasan nilai p yang digunakan untuk menentukan kelayakan variabel adalah 0,25 . Apabila nilai $\mathrm{p}$ yang diperoleh $\leq 0,25$ maka variabel tersebut diikutkan dalam analisis multivariat, namun jika > 0,25 maka tidak di masukan ke pemodelan multivariat

Tabel 3. Seleksi Bivariat

\begin{tabular}{lcc}
\hline \multicolumn{1}{c}{ Nama Variabel } & P Value & Keterangan \\
\hline Riwayat Pengobatan TB & 0,010 & Ikut Multivariat \\
\hline Efek Obat Anti TB & 0,002 & Ikut Multivariat \\
\hline Penyakit Diabetes Melitus & 0,643 & Tidak Ikut Multivariat \\
\hline Status Gizi & 0,633 & Tidak Ikut Multivariat \\
\hline Keteraturan Minum Obat & 0,000 & Ikut Multivariat \\
\hline
\end{tabular}


Hasil seleksi bivariat didapatkan bahwa dari 5 variabel yang ada ternyata hanya ada 3 variabel menghasilkan nilai $\mathrm{P}$ value $<0,25$ yaitu Riwayat Pengobatan TB, Efek Obat Anti TB dan Keteraturan Minum Obat, sehingga hanya 3 variabel tersebut yang masuk ke tahapan analisis multivariate.

\section{Pemodelan Multivariat}

Dalam pemodelan ini, jika terdapat variabel yang mempunyai nilai $\mathrm{p}$ value $>0,05$ maka di keluarkan dari model satu persatu kemudian di hitung perubahan Nilai OR. Jika perubahan nilai OR $<10 \%$ maka variabel tersebut terus di keluarkan dari model, namun jika hasil perhitungan perubahan nilai OR ternyata $\geq 10 \%$ maka variabel tersebut di masukan kembali ke model. Untuk lebih jelas pemodelan multivariat ditampilak pada tabel 4 berikut.

Tabel 4. Pemodelan Multivariat

\begin{tabular}{cccccc}
\hline & & & & \multicolumn{2}{c}{ 95\% C.I.for EXP(B) } \\
\cline { 5 - 6 } No & Variabel & P-Value & OR & Lower & Lower \\
\hline 1 & Riwayat Pengobatan TB & 0,011 & 6,359 & 1,518 & 26,639 \\
\hline 2 & Efek OAT & 0,013 & 6,873 & 1,496 & 31,572 \\
\hline 3 & Kepatuan Minum Obat & 0,009 & 7,192 & 1,644 & 31,452 \\
\hline
\end{tabular}

Dari hasil pemodelan diatas, ternyata semua variabel mempunyai nial $\mathrm{P}$ Value $<$ dari 0,05 maka tidak ada variabel yang di keluarkan dari model, serta tidak ada perhitungan perubahan niali OR. Dengan demikian maka pemodelan ini selesai.

Berdasarkan analisa multivariat adapun variabel yang berpengaruh terhadap terjadinya TB MDR di wilayah kerja Puskesmas Kecamatan Pasar Rebo adalah Riwayat Pengobatan TB, Efek Obat Anti TB dan Kepatuhan Minum Obat Anti TB. Namun dari ke tiga variabel tersebut ternyata variabel Kepatuhan minum obat Anti TB merupakan variabel yang paling dominan mempengaruhi Terjadinya TB MDR, oleh karena mempunyai nilai OR tertingi yaitu 7,192. Dari hasil OR tersebut dapat disimpulkan bahwa responden yang tidak patu minum Obat Anti TB beresiko menjadi menjadi TB MDR 7 kali lebih besar dibanding responden yang patuh minum obat.

Hasil penelitian inipun sejalan dengan penelitian Sarwani, 2012 dimana hasil analisis bivariat dan multivariat menunjukkan ada hubungan antara keteraturan minum obat 
dengan kejadian MDR-TB. Seseorang yang mengkonsumsi obat TB secara tidak teratur mempunya risiko 2,3 kali lebih besar untuk menderita MDR - TB dibandingkan yang mengkonsumsi obat secara teratur (19). Sejalan juga dengan penelitian Ti T et al., (2006) menyatakan bahwa orang yang melakukan pengobatan tidak teratur memiliki risiko terkena MDR-TB 4,8 kali lebih besar dibandingkan dengan yang melakukan pengobatan teratur. (20)

Penelitian Barroso (2003), juga menyebutkan bahwa orang yang melakukan pengobatan tidak teratur memiliki risiko terkena MDR-TB 5,1464 kali lebih besar dibandingkan dengan yang melakukan pengobatan teratur. (21)

Menurut asumsi peneliti, Alasan utama gagalnya pengobatan adalah pasien tidak mau minum obatnya secara teratur dalam waktu yang diharuskan. Pasien biasanya bosan harus minum banyak obat setiap hari selama beberapa bulan. Lamanya waktu pengobatan TB paru yang harus dilakukan selama 6 bulan, dapat saja dijadikan beban oleh penderita sehingga mereka malas untuk melanjutkan proses pengobatan. Adapun bagi penderita yang memiliki keinginan atau motivasi yang kuat akan terhindar dan sembuh dari penyakit dan tetap akan melakukan pengobatan secara teratur. Namun sebaliknya bagi penderita yang kurang memiliki keinginan atau motivasi untuk sembuh, bisa jadi mereka tidak patuh dalam minum obat sesuai dosis dan waktu yang sudah di tentukan. Oleh karena itu salah satu hal utama dalam penanganan kasus TB adalah bagaimana memotivasi penderita agar mereka mau menyelesaikan pengobatannya sesuai waktu yang telah ditetapkan.

Dalam penelitian ini pula diperoleh Nilai Nagelkerke $R$ Square 0,416, yang menunjukkan bahwa kemampuan variabel independen (Riwayat pengobatan TB, Efek Obat Anti TB dan Kepatuhan minum obat Anti TB) hanya mampu menjelaskan variabel dependen (TB MDR) sebesar 0,416 atau 41,6\%. Dengan demikian maka masih ada faktor lain diluar model ini yang menjelaskan kejadian TB MDR sebesar 59,4\%.

\section{SIMPULAN}

Dari hasil penelitian ini dapat disimpulkan bahwa kejadia TB MDR di Pasar Rebo dipengaruhi oleh Riwayat Pengobatan TB, Efek Obat Anti TB, dan Kepatuhan Minum Obat Anti TB. Diantara ketida variabel tersebut, variabel yang paling besar pengaruhnya 
terhadap TB MDR adalah kepatuhan minum obat. Oleh karena itu penelitian ini merekomendasikan:

1. Peningkatan penyuluhan secara berkala kepada pasien TB dan keluarganya tentang kepatuhan minum obat lebih ditekankan lagi tentang konsekuensi kalau tidak patuh. TB MDR terjadi merupakan rangkaian sebab akibat, dari efek obat yang menyebabkan ketidak patuhan minum obat. Efek samping obat yang timbul membuat pasien tidak nyaman, hal ini karena metabolisme obat yang terjadi di hati. Dengan demikian maka perlu ada langkah yang tepat dalam mensiasati efek samping obat ini, agar tidak menjadi pengahalang keberhasilan pengobatan TB, salah satunya dengan memberikan vitamin dan suplemen protektor hati

2. Teratur tidak nya pasien TB dalam menyelesaikan pengobatan TB, sangat tergantung dari peran serta PMO (Petugas Minum Obat). Pasien TB akan menjadi TB MDR bilamana pengobatannya tidak Sukses, apalagi pasien tersebut mempunyai riwayat pengobatan TB sebelumnya. Oleh karena itu, perlu dipantau dan lebih di tingkatlakan lagi peran serta PMO dalam mendukung keberhasilan Pengobatan TB.

3. Petugas perlu selalu mengontrol, memantau status gizi dan pola makan pasien TB setiap kali melakukan pemeriksaan atau setiap kali mengambil obat. Perlu juga memberikan konsultasi kepada pasien tentang efek samping obat yang mungkin akan timbul ketika mengkonsumsinya..

4. Memaksimalkan kegiatan skrining pada pasien DM yang beresiko terkena TB dan skrining pada anggota keluarga yang mungkin selalu kontak dengan pasien.

\section{REFERENSI}

1. World HealthOrganizatio. Global Tuberculosis Report. Geneva : WHO Pres, 2016.

2. Puskesmas Kecamatan Pasar Rebo. Laporan Tahunan Puskesmas Kecamatan Pasar Rebo. Jakarta : s.n., 2017 (Tidak dipublikasikan).

3. Puskesmas Kecamatan Pasar Rebo. Profil Puskesmas Kecamatan Pasar Rebo. Jakarta : s.n., 2016 (Tidak dipublikasikan).

4. Arifin, Nawas. Penatalaksanaan TB MDR danStrategi DOTS Plus. Jakarta: Departemen Pulmonologi dan Ilmu Kedokteran Respirasi FKUI-RSUP Persahabatan, 2010. 
5. Sri Melati Munir, Arifin Nawas, Dianiati K Soetoyo. Pengamatan Pasien Tuberkulosis Parudengan TB MDR di Poliklinik Paru RSUP Persahabatan. Jakarta : Departemen Pulmonologi dan Ilmu Kedokteran Respirasi FKUI-RSUP Persahabatan., 2010.

6. Reviono, P Kusnant, Vicki Eko, Helena Pakiding, Dyah Nurwididiasih. Multidrug Resistant Tuberculosis (MDR-TB): Tinjauan Epidemiologi dan Faktor Risiko Efek Samping Obat Anti Tuberkulosis. Bandung : Majalah Kedokteran, 2014.

7. Hastono, Sutanto Priyo. Modul Analisis Data. Fakultas Kesehatan Masyarakat: Universitas Indonesia, 2007.

8. Lapau, Buchari. Metode Penelitian Kesehatan (edisi revisi). Jakarta: Yayasan Pustaka Obor Indonesia, 2015.

9. Janan, M. Faktor-faktor Risiko yang Berhubungan dengan Peningkatan Prevalensi Kejadian TB MDR di Kabupaten Brebes Tahun 2011-2017. Jakarta: Jurnal Kebijakan Kesehatan Indonesia: JKKI, 2019. 64-70..

10. Mekonnen, F., Tessema, B., Moges, F.,Gelaw, A., Eshetie, S., \& Kumera, G. (2015). Multidrug resistant tuberculosis: prevalence and risk factors in districts of metema and west armachiho. Northwest Ethiopia. : BMC infectious diseases. Vol. 6 (4). 461.

11. Riswanti, Yuni. Faktor-Faktor Yang Berpengaruh Dengan Kegagalan Konversi Penderita Tuberkulosis Paru Basil Tahan Asam (Bta) Positif Pengobatan Fase Intensif Di Kota Magelang Tahun 2013-2014 ( Skripsi). s.l.: Universitas Negeri Semarang, 2014.

12. Kusnanto, P., Eko, V., Pakiding, H., \& Nurwidiasih, D. Multidrug resistant tuberculosis (MDR-TB): tinjauan epidemiologi dan faktor risiko efek samping obat anti tuberkulosis. Bandung : Majalah Kedokteran, (2014). Vol. 46 (4). 189-196..

13. Kementerian Kesehatan RI. Petunjuk Teknis Manajemen Terpadu Pengendalian Tuberkulosis Resisten Obat. Jakarta : Kemenkes RI, 2014.

14. Tirtana, B. T., \& Musrichan, M. . Faktor-faktor yang mempengaruhi keberhasilan pengobatan pada pasien tuberkulosis paru dengan resistensi obat tuberkulosis di Wilayah Jawa Tengah (Doctoral dissertation, Faculty of Medicine). 2011.

15. Mulyanto, H. Hubungan Antara 5 (Lima) Indikator Perilaku Hidup Bersih Dan Sehat (Phbs) Dengan Tuberkulosis Multidrug Resistant (TB-MDR) DI RSU DR. Saiful Anwar Malang (Doctoral dissertation). s.l. : Universitas Airlangga, 2014. 
16. PERKENI. Pengelolaan dan Pencegahan Diabetes Melitus Tipe 2 di Indonesia. Jakarta : PERKENI, 2015.

17. World Health Organization. Global Tuberculosis Report 2008. Geneva : WHO Press, 2008.

18. Niviasari, D. N., Saraswati, L. D., \& Martini, M. Faktor-Faktor Yang Berhubungan Dengan Status Kesembuhan Penderita Tuberkulosis Paru. s.1. : Jurnal Kesehatan Masyarakat (e-Journal), 2017. Vol. 3 (3).

19. Sarwani, D., Nurlaela, S., \& Isnani, Z. A. Analisis faktor risiko multidrug resistant tuberculosis (MDR-TB) (Studi Kasus di BP4 Purwokerto). s.l. : JKM, 2013. Vol. 8 (1). 62-8.

20. Ti, T., Lwin, T., Mar, T. T., Maung, W., Noe, P., Htun, A., ... \& Paramasivan, C. N. National anti-tuberculosis drug resistance survey, 2002, in Myanmar. s.1.: The International Journal of Tuberculosis and Lung Disease , 2006. Vol. 10 (10).

21. Arroso, E. C., Mota, R. M. S., Santos, R. O., Sousa, A. L. O., Barroso, J. B., \& Rodrigues, J. L. N.B. Risk factors for acquired multidrug-resistant tuberculosis. s.l. : Jornal de Pneumologia, 2003. Vol. 29 (2). 89-97. 